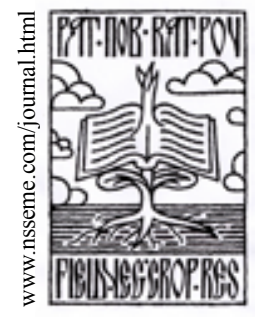

\title{
Breeding of Minor Fodder Crops for Sustainable Agriculture
}

\author{
Tomas Vymyslicky
}

\author{
received: 13 November 2013, accepted: 6 March 2014 \\ published online: 2 June 2014 \\ (c) 2014 IFVC \\ doi:10.5937/ratpov51-4896
}

\begin{abstract}
Summary: There is a lack of knowledge on the diversity and geographical distribution of less utilized species in agriculture. Breeding programmes of minor crops are very important for increasing the diversity in agriculture and for sustainable agriculture. Input materials in most cases are crop wild relatives of main cultivated forage species like alfalfa, red clover, white clover, etc. Gathering, growing and breeding of crop wild relatives has a long tradition in the Czech Republic. In the workplace in Troubsko it has been done for 60 years. The result of this activity is 21 registered varieties of different minor crops (Trifolium pannonicum, Lablab purpureus, Lathyrus sativus, Trigonella foenum-graecum etc.) and many breeding lines included in the state registration trials (Astragalus cicer, Trifolium alpestre, Galega orientalis etc.). One of the results of breeding programme is a unique variety Trifolium pratense $x$ Trifolium medium (Trifolium $x$ permixtum) - PRAMEDI. The variety was bred as interspecific hybridisation of the red clover (Trifolium pratense L.) cv. Tatra $(2 \mathrm{n}=4 \mathrm{x}=$ 28 ) and zigzag clover (T. medium L.) $(2 \mathrm{n}=8 \mathrm{x}=64)$. It is perennial legume species, which is suitable as substitution of the red clover, especially in dry and warm regions. The height, flowering time and quality are comparable to standard tetraploid red clover varieties. By the plants short underground rhizomes are frequent and the plants have better persistence.
\end{abstract}

Keywords: biodiversity, breeding, fodder crops, food legumes, oil crops

\section{Introduction}

The total number of plant species which are cultivated as agricultural or horticultural crops, can be close to 7,000, but only about 30 species "feed the world". About 6 millions of accessions have been collected and conserved in gene banks. About half of all accessions are advanced cultivars or breeders' lines, only a third of them are landraces or old cultivars, and about $15 \%$ are crop wild relatives, weedy or wild species. Only a third of all accessions are characterized. There is a gap in the collections regarding minor crops and underutilized species; in particular landraces and wild relatives of crops are underrepresented in gene banks. There is a lack of knowledge about the diversity and geographical distribution of less

Vymyslicky T.

Research Institute for Fodder Crops, Ltd., Zahradni 1, 66441 Troubsko, Czech Republic

Agricultural Research, Ltd. Department of genetic resources e-mail: vymyslicky@vupt.cz utilized species in agriculture. The need for more attention on such crops and crop-weed complexes in conservation and utilization programmes is evident. Further exploration of minor and underutilized species, collection of these genetic resources and the assessment of genetic diversity within and between landraces should have priority in the activities of gene banks. It is also necessary to develop better methods of characterization and evaluation of germplasm collections, to improve strategies for conservation of collected germplasm, and to increase the utilization of plant genetic resources. The most effective methods for conservation in considered plant groups (crops, their wild relatives, weeds and wild plants) are different. The strategies include ex situ conservation (management of gene

Acknowledgements:

The results were obtained in the frame of institutional project no. MSM 2629608001, financed by the Ministry of Education, Youth and Sports of the Czech Republic; and institutional funding on long-term conceptual development of research organisation, financed by the Ministry of Agriculture of the Czech Republic. 
banks), conservation and management on farm (monitoring and protection of agro-ecosystems), in situ conservation (monitoring and protection of natural ecosystems). The most effective way of genetic diversity assessment within a given taxon is also a combination of different methods, combining morphological, agronomic and molecular characterization of genetic diversity. The ongoing process of gene-erosion requires clear decisions for future strategies (Gladis \& Hammer 2000).

Classification of economically important plants and the list of all taxa (not only minor crops) for Europe were published by Hulden (2000). Survey of crops of European origin was published by Hammer \& Spahillari (2000). Many of the crop species are considered to be minor at a global scale, but some of them are important locally for food security in the developing world. Recent development of large-scale genomic and genetic resources in these crops is observed. These resources have the potential to accelerate gene discovery and initiate molecular breeding in these crops, in order to enhance the crop productivity to ensure food security in developing countries (Varshney et al. 2010). An example from Italy focused on establishment of the meaning of minor vegetable crops (MVC) was presented by Bianco (2009). Italy has a great diversity of MVC, some grown since ancient times, 168 of them are mentioned, and common and Latin names are reported. The Italian gene bank and the collection holders of some MVC genetic resources are indicated. The evolution of harvested outdoor and greenhouse crops in the last 30 years are reported. The resistance and tolerance to some soil, climatic stress and gaseous pollutants are mentioned. The importance of soilless cultivation and organic production of MVC in Italy is also discussed.

On the other hand, new breeding techniques based on latest discoveries of plant molecular biology and technical developments have led to development of new genotypes of improved plants with sophisticated changes in the genome. Impact of such plant varieties and their acceptance is discussed widely in Europe (Ovesná 2013).

Breeding programmes of minor crops are very important for increasing the diversity in agriculture and for sustainable agriculture. Big potential of minor crops is in connection with climatic change. Input materials for breeding in minor crops are in most cases wild ecotypes. In forages, a lot of minor crops are crop wild relatives of main cultivated forage species like alfalfa, red clover, white clover, etc. Gathering, growing and breeding of crop wild relatives has a long tradition in the Czech Republic. In the workplace in Troubsko it has been done for 60 years. Since the seventies the systematic collection, field evaluation and breeding of main domestic and foreign fodder species has been carried out (Vacek 1963). It is in accordance to other countries and Fabaceae species (Martincová \& Kizeková 2010, Jahufer et al. 1994, Kouame \& Quesenberry 1993, Vymyslický et al. 2012, etc.). The result of this activity is 21 registered varieties of different minor crops (Trifolium pannonicum, Lablab purpureus, Lathyrus sativus, Trigonella foenum-graecum, etc.) and many breeding lines included in the state registration trials (Astragalus cicer, Trifolium alpestre, Galega orientalis, etc.).

\section{Results and Discussion}

In the following text new varieties and breeding lines launched from our breeding programme of minor crops in the last years are presented. Varieties, breeding lines and interspecific hybrids are the sub-chapters. Their main use is in sustainable agriculture as minor forage crops, food legumes, intercrops or oil crops. They were bred mostly from wild species or old landraces. Many of them are very suitable for organic agriculture or small-plot growing conditions, like gardens, small fields, etc.

\section{1) Varieties}

Phaseolus vulgaris HYNEK was registered in 2011. It was bred from material originating in botanical garden by the method of negative selection, focused on elimination of the twining plants. Plants are annual, shrubby. Typical is presence of violet colour on the plants, including pods. Plant creates branched root with nodule bacteria. Flowers are violet; pod has 2-8 small black rounded seeds. It is a pulse crop with high protein content. This bean variety is suitable for use in food industry, beside classical use it could be used for flour production. The flour could be added into home and industrial mixtures for bread baking. The variety has very good drought tolerance, and is able of nitrogen fixation. It is a thermophilous crop; sowing time is in the last days of April or beginning of May (because of sensitivity to late spring frosts). The length of vegetation season is according to climatic condition on average 150 days, seeds are harvested in September. It is necessary to take care about the occurrence of weevils both during the vegetation and the storage. 
Trifolium alexandrinum FARAON is an annual species, similar to alfalfa. Variety was registered in 2011. Stems are erect to procumbent, hollow. Leaves are big, elliptic to lanceolate shape. Flower heads are rounded and have long stalks. Flowers are white to yellow white. This species could be grown for forage in pure stand, as intercrop, or in mixture with annual ryegrass. As a consequence of slow initial development there are problems with weed infestation, so the first cut done early is necessary. It regularly produces three cuts for hay. Seed production is possible after the first hay cut.

Lablab purpureus ROBIN was registered in 2011. It was bred from material originating in botanical garden by the method of negative selection. Plants are annual, erect, with twining stem. The species has big leaves. Plant creates branched root with nodule bacteria. Flowers are violet; pod has 1-2 dark brown seeds with white stripe. It could be used as pulse crop for food industry, having high protein content. Field cultivation is successful only in the warmest part of the Czech Republic or central Europe. In the other regions it could be grown in the greenhouses. It is very drought resistant, having good nitrogen fixation, so it is a suitable species for growing on soils with a very low fertility. Sowing time is in the last days of April or beginning of May (because of sensitivity to late spring frosts). The length of vegetation season is according to climatic condition on average 180 days, seed harvest is in October, but it could be harvested even later, after the first frost. No pests and diseases have been observed on this plant species.

Lathyrus sativus RADIM is a variety that was registered in 2011. It was bred by open space hybridisation of materials originating in the White Carpathians (region at the border with Slovakia). Plants are annual, procumbent. Leaves are narrow and long; root is branched with nodule bacteria. Flowers are two-coloured: white and purple. In the pod there are 1-2 cream coloured seeds. Grass pea has high protein content and medium content of beta-N-oxalylL-alfa, beta-diaminopropionic acid (betaODAP): $0.46 \mathrm{~g} / 100 \mathrm{~g}$ seeds (2006) and $0.47 \mathrm{~g} /$ $100 \mathrm{~g}$ seeds (2007). It is a crop suitable for use in the food industry (for flour, for consumption of whole cooked or roasted seeds). It is important to mention that grass pea is suitable as a part of diverse diet, not as regular meal. Fresh and dry biomass could be used for feeding the domestic animals, seeds could be used as feed in the form of grind. Due to its high drought resistance and nitrogen fixing ability it is suitable for fertilising sandy, podsolic soils, heaps, and for increasing the yields of subsequent crops on arable land. It is thermophilous crop, suitable for warm and dry regions. As intercrop it could be grown also in higher altitudes. Sowing time is in April, it is better to utilise the humidity in the soil remaining from the winter. The length of vegetation season is according to climatic condition on average 120 days, seed harvest in August. No pests and diseases have been observed on this plant species.

Crambe abyssinica KATKA was registered in 2010. The plant is used as annual spring oil crop from the family Brassicaceae, it is suitable for dry conditions. Plant height is $50-80 \mathrm{~cm}$, flowering time is in June. Thousand seed weight is 6-7 g. Seeds contain oil suitable for technical purposes. Erucic acid content is $50-55 \%$ and oil content $36 \%$. It could be used as oil crop, intercrop and also as feed source for pollinators. Agrotechnology: Sowing rate 5-10 kg ha ${ }^{-1}$. The length of vegetation season is according to climatic condition on average 110-130 days, seed harvest in August. Seed yield 1-1.5 t ha-1. Harvest without desiccation is possible.

Trifolium pannonicum PANON was registered in 2009. It is a perennial clover species, height to $50 \mathrm{~cm}$, with very hairy long leaves. Inflorescence is cylindrical with white coloured flowers. Flowering time is in June. Thousand seed weight is $2.8 \mathrm{~g}$. It is a native species of our flora. Area of distribution covers south-eastern part of Europe: Hungary, Ukraine, the Balkans and Italy. In the Czech Republic it grows on dry steppe meadows, shrubs, and sunny hillsides; especially in the White Carpathians. The species prefers good soil quality, neutral or alkaline $\mathrm{pH}$. It is suitable as feed source for bumblebees and pollinators. It provides balanced yields in two cuts during whole cultivation time, which is recommended to be 7 years. It has good forage quality, but for cattle it is not as tasty as the red clover; it is very good as a component of permanent grasslands and pastures. Sowing time is in March and April, sowing rate $15 \mathrm{~kg} \mathrm{ha}^{-1}$.

Phacelia congesta FIONA is an annual plant, with $30-90 \mathrm{~cm}$ high stems. It is similar to Phacelia tanacetifolia, but there are several differences. Phacelia congesta has leaves only once pinnate, with longer stalk, they are longer and wider, and thus the species has bigger leaf area. Plants of $P$. congesta are smaller, with shorter internodes, compared to $P$. tanancetifolia. Flowers are purple, or lavender blue; they are shorter and wider with shorter stamens. Inflorescence is dense and 
curled, gradually unrolled from its basal part. $P$. congesta is more adaptable to extreme conditions, so it is good for sandy and unfertile soils. It is a very good feed source for pollinators, even better than $P$. tanacetifolia. The species has good resistance to pests and diseases. It is very good as intercrop.

2) Breeding lines - materials included in the state registration trials

Trifolium ochroleucon HELIAN. The species is native to western, central and southern Europe; in the east up to Ukraine, Turkey and Iran. In the Czech Republic it grows in warmer areas, mainly in the eastern part of the country. The species is similar to T. pannonicum. It is a perennial clover species with creeping rhizomes. Stems are about $40 \mathrm{~cm}$ high, hairy. Flowers are white-yellow. Flowering time is in June. The species prefers dry meadows and pastures, forest margins and clearings. It could be used as a component of permanent grasslands and pastures. Sowing time is in March and April, sowing rate $15 \mathrm{~kg} \mathrm{ha}^{-1}$. It is suitable as feed source for bumblebees and pollinators.

Trifolium fragiferum FRAGAN is a perennial species, native to all the Europe. In the Czech Republic it grows on salty soils, with high content of nutrients and especially nitrogen. It is a typical species for salty meadows, paths, pastures and shores of water reservoirs. The species belongs to endangered plant species. In the sterile state it is almost the same as $T$. repens. Typical are inflated infructescences, resembling hairy brownish raspberry. It is an excellent component of pastures, resistant to grazing, with fast re-growth, spreading with long creeping stolons. The species has high content of nitrogen substances. It can survive flooding up to two months, so it can be used instead of white clover. It could be used as component of permanent grasslands and pastures. It is suitable as feed source for bumblebees and pollinators. Agrotechnology is the same as for $T$. repens.

Trifolium arvense ROLAN is an annual species, which is native to almost all the Europe. It is common in the Czech Republic; growing on dry, sandy, preferably acidic soils. It grows on fallows, balks, sandy places, rock crumbles, etc. It has bitter taste because of high tannin content, and the stem is tough. It is interesting from the point of view of adding organic matter and nitrogen to nutrient poor soils. It is suitable as component for specific clover-grass mixtures for permanent and temporary grasslands, where it is maintained by re-seeding. It is suitable as feed source for bumblebees and pollinators.
Oenothera biennis BIENALA is a biennial oil crop. It originates from the Northern America. It can grow up to $1.5 \mathrm{~m}$. In the first year it produces only leaf rosettes. Flowers are yellow. This species prefers dry soil with low nutrient content, but with high sunshine duration. Sowing rate is 3-5 $\mathrm{kg} \mathrm{ha}^{-1}$. Oil pressed from the seeds contains gamalinolenic (10\%) and linolenic acid (65-70\%).

Galega orientalis LENA is a perennial legume species, around $120 \mathrm{~cm}$ in height; native to Caucasus, Transcaucasia, and Armenia. Leaves have 5-9 couples of leaflets, which are lanceolate, elongate, sharp and glabrous with short petiole. Stems are erect, with white or pink flowers in racemes. The fruit is pod bearing 5-8 light brown reniform seeds. Plants are pollinated by bees and bumblebees. It is very persistent, it can survive for 10-13 years; resistant to frosts and droughts. In the sowing year it develops very slowly and provides one to two cuts. In the sowing year the stand does not flower. From the second year of vegetation two cuts are provided. The best yields are in around the seventh year and then slowly decrease. Flowering time is in May and June. Fast spring re-growth is even better than in alfalfa. The cuts are recommended in the stage of the occurrence of the first flowers, later the stems lignifies. The plant has numerous root shoots, roots are bearing nodule bacteria, with nitrogen fixing ability.

Camelina sativa ZUZANA is an annual Brassicaceae crop species, could be used as oil or intercrop species. It has short vegetation period, around 90-110 days. It is drought and cold resistant. The oil could be used in food industry. It is an insect pollinating crop, especially by bees. Sowing is in April, sowing rate $7-11 \mathrm{~kg} \mathrm{ha}^{-1}$. Short vegetation time enables its cultivation as a second crop in the year; it could be grown even after early potatoes. It is more resistant to pests than oilseed rape. Among diseases, Botrytis cinerea was observed on the plants. Seed yield is 1-2 $\mathrm{tha}^{-1}$.

Astragalus cicer ASTRA is a perennial species; growing in warmer areas in grasslands, on balks, in the shrubs, up to submontane regions. The plant has divaricated habit; it is drought and frost resistant. Leaves are persistent, they are sweet and thus attractive for wild animals, especially young ones. Some authors mention that it is a good forage crop, other point out the content of glycosides which are harmful to animals. In the USA and Canada the species is grown on sheep pastures. Advantage of the species is the creation of underground rhizomes, up to one meter from mother plant, so the plant spreads significantly and 
fast. Because of this fact, the plant is considered to be good anti-erosion crop. Roots are colonised by symbiotic nitrogen fixing bacteria. The species could be used as fodder crop, as component of species rich pasture and meadow mixtures; it is good for use in anti-erosion mixtures and for the special mixtures used for leaving the soil without tillage. Sowing rate is $15 \mathrm{~kg} \mathrm{ha}^{-1}$, but it should be taken into account that significant amount of seeds are hard seeds with dormancy.

3) Interspecific hybrid of Trifolium pratense and Trifolium medium; Trifolium $x$ permixtum variety PRAMEDI

In the year 2010 the hybrid material was registered as breeding line into the state variety trials for granting the property rights to the variety. In the year 2012 property rights to the variety PRAMEDI were granted. It is the first European, maybe world clover variety originating in interspecific hybridisation of Trifolium pratense and Trifolium medium. Parental species are by classical methods almost uncrossable. Modern in vitro methods enabled the creation of this hybrid, combining characters of both parental species.

The variety was bred from tetraploid Trifolium pratense cultivar Tatra $(2 \mathrm{n}=2 \mathrm{x}=28)$ and Trifolium medium $(2 \mathrm{n}=8 \mathrm{x}=64)$. At the beginning only 10 plants of $F 1$ generation were acquired after manual crossing and growing of not ripened hybrid embryos under in vitro conditions into mature plants. In the following years population of plants originating in hybridisation of F2 generation with $T$. pratense cv. Amos for 5 generations was established. Plant evaluation by flow cytometry enabled selections of plants with higher DNA content compared to tetraploid $T$. pratense. Hybrid character was confirmed beside the measurement of DNA content also at the cytogenetic level basing on increased chromosome number.

The evaluation of characters in three years confirmed highly statistically significant differences among hybrids and parents. Stem number per plant is statistically significantly higher by the hybrids compared to both parents. This character determined the tuft characteristic. By the plants of hybrid origin short underground rhizomes could be observed. This character is not present in $T$. pratense, but was introduced from T. medium. Because of rhizomes, plants have better persistence. Seed yield is comparable to both parental species.

It could be used as forage crop in pure stand or in mixtures with grasses. It is suitable for direct forage or for conserving via silaging or haylaging. Other use is as a component of clover grass mixtures for establishing recreation of permanent grasslands. It is a perennial legume species, which is suitable as substitution of the red clover, especially in dry and warm regions. The height, flowering time and biomass quality are comparable to standard tetraploid red clover varieties.

\section{Conclusions}

There is a lack of knowledge on the diversity and geographical distribution of less utilized species in agriculture. Breeding programmes of minor crops are very important for increasing the diversity in agriculture and for sustainable agriculture. Input materials in most cases are crop wild relatives of main cultivated forage species like alfalfa, red clover, white clover, etc. In the workplace in Troubsko breeding has been done for 60 years. The result of this activity is 21 registered varieties of different minor crops and many breeding lines included in the state registration trials. One of the results of breeding programme is unique variety Trifolium $x$ permixtum PRAMEDI. The variety was bred as interspecific hybridisation of the red and zigzag clover. It is perennial legume species, which is suitable as substitution of the red clover, especially in dry and warm regions. The height, flowering time and quality are comparable to standard tetraploid red clover varieties. By the plants short underground rhizomes are frequent and the plants have better persistence.

\section{References}

Bianco, V. (2009). Minor vegetable crops in Italy. Italus Hortus, $16(1): 1-21$

Gladis, T., \& Hammer, K. (2000). The relevance of plant genetic resources in plant breeding. Animal Breeding and Animal Genetic Resources, 3-13.

Hammer, K., \& Spahillari, M. (2000). Crops of European origin. Report of a network coordinating group on minor crops. Ad hoc meeting, Turku, Finland, 16 June, 1999, pp. 35-43.

Hulden, M. (2000): Classification of economically important plants. Report of a network coordinating group on minor crops. Ad hoc meeting, Turku, Finland, 16 June, 1999, 44-55.

Jahufer, M.Z.Z., Cooper, M., \& Brien, L.A. (1994). Genotypic variation for stolon and other morphological attributes of white clover (Trifolium repens L.). Populations and their influence on herbage yield in the summer rainfall region of New South Wales. Aust J Agric Res, 45(3), 703720.

Kouame, C.N., \& Quesenberry, K.H. (1993). Cluster analysis of a world collection of red clover germplasm. Genet Resour Crop Evol, 40(1), 39-47. doi:10.1007/BF00053463 
Martincová, J., \& Kizeková, M. (2010). Hodnotenie genetických zdrojov tráv a datelinovín vo vztahu $\mathrm{k}$ morfologickým a produkčným vlastnostiam. In Nové poznatky z genetiky a šlachtenia pol'nohospodárskych rastlín. Zborník zo 17. vedeckej konferencie, CVRV Pieštany, 26.-27.10.2010. (pp. 31-34)

Ovesná, J. (2013). New Plant Breeding Techniques. Seed and Seedlings, XI. Scientific and technical seminar, 20-23.

Vacek, V. (1963). Study, maintaining and use of the world assortrment of fodder plants. I. Wild Flora. A. Family Fabaceaes. VÚP Troubsko. [in Czech].
Varshney, R.K., Glaszmann, J.C., Leung, H., \& Ribaut, J.M. (2010). More genomic resources for less-studied crops. Trends in Biotechnology, 28(9): 452-460.

Vymyslicky, T., Smarda, P., Pelikan, J., Cholastova, T., Nedelnik, J., Moravcova, H., . . Polakova, M. (2012). Evaluation of the Czech core collection of Trifolium pratense, including morphological, molecular and phytopathological data. African Journal of Biotechnology, 11(15), 3583-3595.

\section{Oplemenjivanje manje poznatih krmnih biljaka za održivu poljoprivredu}

\section{Tomas Vymyslicky}

Sažetak: Nema dovoljno saznanja o diverzitetu i geografskoj distribuciji manje korišćenih poljoprivrednih vrsta. Oplemenjivački programi manje korišćenih biljaka su veoma važni za povećanje diverziteta u poljoprivredi i za održivu poljoprivredu. Ulazni materijali u većini slučajeva su divlji srodnici glavnih gajenih krmnih biljaka poput lucerke, crvene deteline, bele deteline, itd. Skupljanje, gajenje i oplemenjivanje divljih srodnika ima dugu tradiciju u Republici Češkoj, a već 60 godina u Institutu za krmno bilje, Trubsko. Rezultat ove aktivnosti je 21 registrovana sorta različitih manje korišćenih biljaka (Trifolium pannonicum, Lablab purpureus, Lathyrus sativus, Trigonella foenum-graecum, itd.) i mnogo oplemenjivačkih linija uključenih u oglede državne komisije (Astragalus cicer, Trifolium alpestre, Galega orientalis, itd.). Jedan od rezultata oplemenjivačkog programa je jedinstvena sorta Trifolium pratense $\mathrm{x}$ Trifolium medium (Trifolium x permixtum) - PRAMEDI. Ova sorta je dobijena interspecijes hibridizacijom crvene deteline (Trifolium pratense L.) sorte Tatra $(2 \mathrm{n}=4 \mathrm{x}=28)$ i srednje deteline $($ T. medium L.) $(2 \mathrm{n}=$ $8 \mathrm{x}=64$ ). Ovo je višegodišnja mahunarska vrsta koja je pogodna kao zamena za crvenu detelinu, posebno u suvim i toplim oblastima. Visina, vreme cvetanja i kvalitet su kao kod sorti standardne tetraploidne crvene deteline. Kratki podzemni rizomi su česti, a biljke su bolje postojanosti.

Ključne reči: biodiverzitet, krmno bilje, mahunarke za ishranu, oplemenjivanje, uljane kulture 